\title{
Susceptibility assessment of soil erosion in overlaying diluvial fan of shallow underground pipelines
}

\author{
Qingdong Wang ${ }^{1} \cdot$ Yingbin Zhang ${ }^{1,2} \cdot$ Qingfeng $\mathrm{Lv}^{3} \cdot$ Chenlin Xiang ${ }^{1} \cdot$ Xiao Xia $^{1} \cdot$ Jing Liu $^{1}$
}

Received: 24 May 2019 / Accepted: 29 November 2020 / Published online: 7 January 2021

(C) The Author(s) 2021

\begin{abstract}
Soil erosion is a serious hazards occurring in overlaying diluvial fans of shallow underground pipelines. To learn the extent of soil erosion in such landforms, we propose a method of susceptibility assessment of soil erosion based on a case study of the Chaka diluvial fan, Qinghai Province, China. First, we conducted a field investigation at 24 sites, to obtain the land surface properties. Then, vital information such as soil anti-scouribility, permeability, density, sectional water volume, and pipeline burial depth was collected. The slope grade and the vegetation index were determined with the geographic information system (GIS) technology. Further, the analytic hierarchy process (AHP) was used to determine the weight of various indices on the potential susceptibility of shallow underground pipelines. The susceptibility classification of the study area soil erosion was obtained based on the GIS overlay analysis tool. Lastly, the susceptibility classification was compared with the results of the field investigation. Their consistency indicates that the proposed method can be successfully implemented to accurately assess soil erosion. The erosion mechanism indicates that occlusion and cementation have an important influence on the susceptibility intensity in overlaying diluvial fans of shallow underground pipelines.
\end{abstract}

Keywords Soil erosion · Diluvial fan · Geographic information system (GIS) $\cdot$ Susceptibility assessment $\cdot$ Weight

\section{Introduction}

Alluvial/diluvial fans are sedimentary landforms that develop at the base of mountain fronts where confined feeder streams emerge by catching and releasing their sediment load into unconfined zones (Bull 1977; Clevis et al. 2003). Spreading their loads in a radiating pattern from a single apex, they form channels with complex shapes such as reticulate and dendritic. These types of fans are common fluvial landforms linked to the activity of torrential streams which can be subject to a variety of different flow processes (Santo et al. 2015;

Yingbin Zhang

yingbinz719@swjtu.edu.cn

1 Department of Geotechnical Engineering, School of Civil Engineering, Southwest Jiaotong University, Chengdu 610031, China

2 Key Laboratory of Transportation Tunnel Engineering, Ministry of Education, Southwest Jiaotong University, Chengdu 610031, China

3 Key Laboratory of Mechanics on Western Disaster and Environment Mechanics, Lanzhou University, Lanzhou 730000, China
Sancho et al. 2008). The erosion processes are complex and influenced by many factors.

Many studies have focused on understanding the soil erosion on the alluvial fan. On the one hand, the evolution of alluvial fans is studied using a combination of geomorphological and sedimentological techniques, where the patterns of erosion are reconstructed (Roberts et al. 1999; Tipping and Halliday 2010; Yang et al. 2011). On the other hand, several studies have exploited the capacity of the sedimentary basins to retain the eroded material and derived erosion fluxes from regional mass balance calculations (Kuhlemann et al. 2002; Barnes and Heins 2010; Hinderer 2012). The surface of a catchment and the volume and age of the eroded sediments deposited at its outlet can be used to derive the mean denudation rate. The space and time variation of the mean denudation rate can be translated into variations in the tectonic uplift or climatic forcing (Kuhlemann et al. 2002; Barnes and Heins 2010). Furthermore, some researchers measured the averaged erosion rates, landscape development, and uplift rates based on the cosmogenic nuclide ${ }^{10} \mathrm{Be}$ and ${ }^{26} \mathrm{Al}$ concentrations, which are particularly useful for estimating the long-term "background" rates of erosion. This is because cosmogenic nuclide concentrations are insensitive to recent changes, 
which reflect long-term tectonic process of plate boundaries (Granger et al. 1996; Nishiizumi et al. 2005). These methods are significant and critical for revealing the denudation rate and emplacement of diluvial fans in geological process, yet not suitable for short-term rainfall-induced soil erosion.

Other researchers have proposed several quantitative models to analyze the process of rainfall-induced soil erosion (Merritt et al. 2003; Aksoy and Kavvas 2005; de Vente and Poesen 2005; Cuomo et al. 2015, 2016). These models can be divided into three categories: empirical, conceptual, and physically based models. Empirical models are often used to recognize the source areas of soil erosion, such models include the famous Universal Soil Loss Equation (USLE; Wischmeier and Smith 1978) and the SEdiment Delivery Distributed (SEDD) model (Ferro and Porto 2000). All of the empirical models cannot account for the deposition and remobilization of sediments, which limits the application of these models. Conceptual models involve general descriptions of catchment processes without considering the specific details of catchment process interactions (Sorooshian 1991), for example, AGriculture NonPoint Source (AGNPS) model (Young et al. 1989). The drawbacks of conceptual models are that calibration varies with sites and that soil properties and rainfall characteristics are considered indirectly (Cuomo et al. 2015). Physically based approaches describe the features and interactions of all the rainfall-induced processes in a catchment. Accurately predictions of annual runoff and soil loss based on the EUROpean Soil Erosion Model (EUROSEM; Morgan et al. 1998) were reported by Veihe et al. (2001) for some catchments in Central America. One of the most encouraging of the physically based models is the LImburg Soil Erosion Model (LISEM; De Roo et al. 1996; De Roo and Jetten 1999), which has been applied to small $\left(<10 \mathrm{~km}^{2}\right.$; Hessel et al. 2003) and medium-sized ( $>50 \mathrm{~km}^{2}$; Baartman et al. 2012) mountain basins; however, it assessed the performance and uncertainties of LISEM towards quantitative estimates of solid discharge and concentration. The major drawbacks of this category model are that corresponding calibrations are required for different scale runoff events and that soil loss may be overestimated (Hessel et al. 2006).

In most of the real cases, very limited information is available, such as peak discharge (of water and sediments) and sediment concentration; thus, the calibration of any erosion model is quite difficult and uncertain (Cuomo et al. 2016). Furthermore, the model complexity is determined by the detail of the catchment processes simulated (Merritt et al. 2003). Complex models suffer from problems with error accumulation and model identifiability, due to over-parameterization (Beven 1989). Therefore, it is necessary to put forward a practical and efficient assessment of soil erosion method.

Human-built structures such as pipelines and railways are usually located on the leading edge of the diluvial fan, because the water volume is relatively low and the terrain is relatively flat. It is well-known that the spatial and temporal distribution of diluvial deposits in relation to erosional gully development (Eriksson et al. 2000) and the erosion during the formation and development of diluvial fans have a great impact on human activities. However, there have been no accurate, widely applicable methods for assessing the susceptibility of erosion on the leading edge of diluvial fans under intermittent rivers. Susceptibility maps for different processes usually subdivide the terrain into zones with different likelihoods that a certain process type may occur (Corominas et al. 2013). Therefore, it is important to assess the soil erosion of the leading edge of the diluvial fan under intermittent rivers during a stable period.

This study proposes a method for susceptibility assessment of soil erosion. The method is applied for susceptibility assessments of the soil erosion in the overlaying diluvial fan of shallow underground pipelines, and the evaluation results are compared with actual engineering results. Furthermore, the mechanism of soil erosion is discussed according to particle size and cementation.

\section{Soil erosion susceptibility assessment method}

The influencing indicators of soil erosion mainly include specific factors such as slope geometry, vegetation cover, soil type, surface roughness, and rainfall characteristics (Cuomo et al. 2016). The susceptibility assessment method of soil erosion proposed in this study is based on indicators of soil erosion that include internal factors such as anti-scourability, permeability, and density, and external factors such as water flow, slope, and vegetation, as well as factors of the project itself, such as pipeline burial depth. These factors are weighted according to reliable methods such as the analytic hierarchy process (AHP) and principal component analysis (PCA). Taking the AHP as an example, we need to obtain parameters such as the maximum characteristic root, random consistency index, and consistency index.

The susceptibility intensity of the study area is obtained by using the weighted overlay analysis tool of the GIS software. According to the natural breakpoint method, the evaluation results are divided into five levels. During the field investigation, according to the principle of proximity and susceptibility intensity similarity of the evaluation results, the buffer area is divided into small areas. Then, we investigate the small area, which is also convenient for comparative analysis. The flow chart of the evaluation method is shown in Fig. 1.

To verify the effectiveness of the proposed soil erosion susceptibility assessment method, we consider the oil and gas pipeline crossing the diluvial fan in a case study, and use the proposed method to conduct the soil erosion susceptibility assessment of the pipeline and compare it with the erosion results of the field survey. 
Fig. 1 Flow chart of the proposed susceptibility assessment method
Flow chart of soil erosion susceptibility assessment method

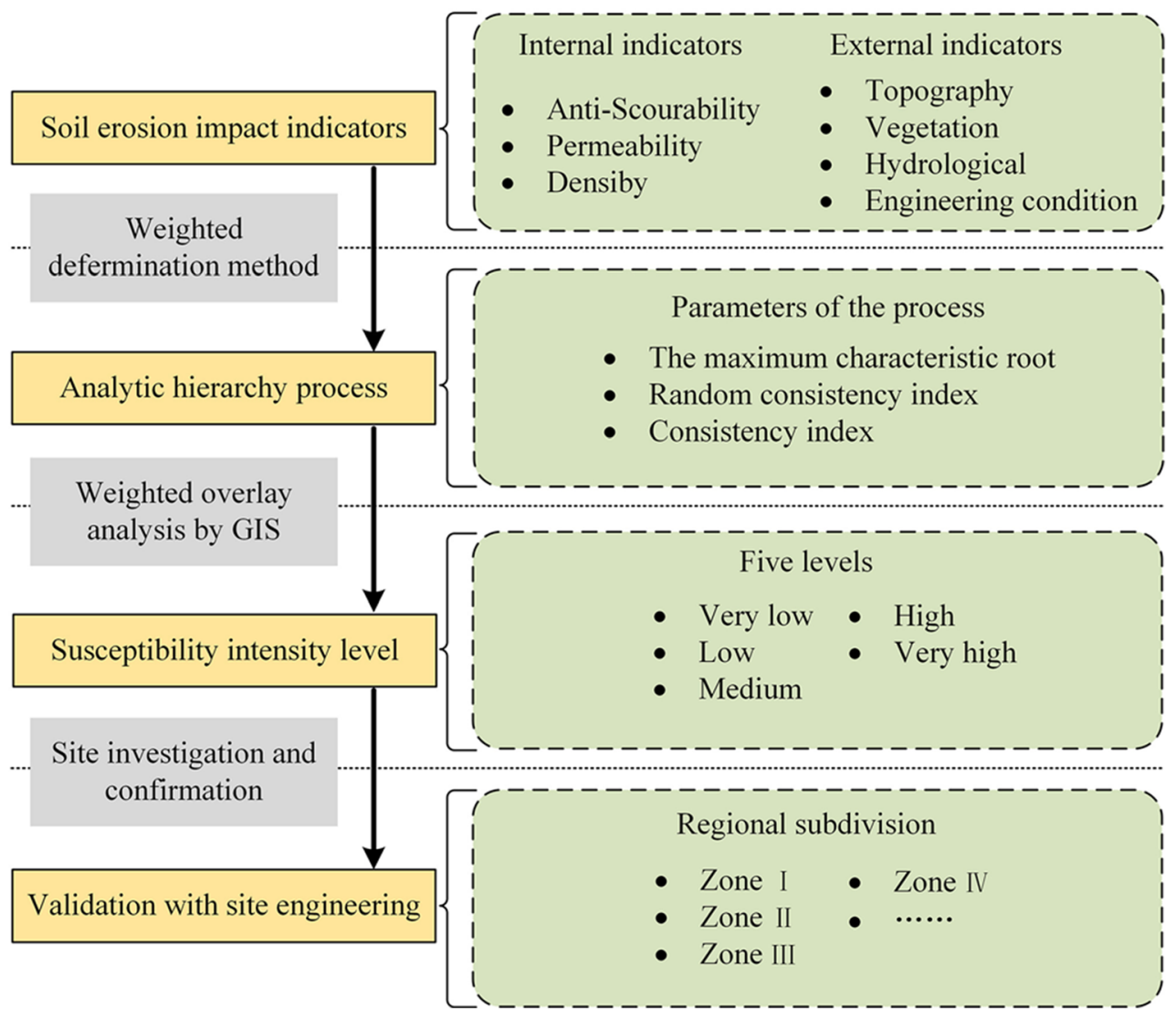

\section{Geologic setting}

The study area is located on the diluvial fan situated approximately $20 \mathrm{~km}$ southwest of the Chaka County, Qinghai Province, western China (Fig. 2a). As shown in Fig. 2b, the mountain water converges and flows out of the water outlet. As a result, the land surface of the fan is carved in different sizes and complex shapes by the intermittent water. Figure $2 \mathrm{c}$ shows the side view of the fan; the pipe pile is surrounded by a black ellipse.

The study area has a width of approximately $31 \mathrm{~km}$ from east to west, an area of approximately $497 \mathrm{~km}^{2}$, and an altitude of $3064-4831 \mathrm{~m}$. It is windy and characterized by a large evaporation, cold and oxygen deficiency, long sunshine, and strong radiation. Rainfall in the fan zone is greatly affected by topography and the airflow in the Bengal Bay. The annual average rainfall is $17.6-764.4 \mathrm{~mm}$, which is typical for the alpine, desert, and drought climate of the area.

The continental crust of the Qinghai Province and the coastal area has planar block and vertical stratification characteristics. The diluvial fan is in the Qaidam-Kunlun area. According to the characteristic of its stratigraphic and spatial distribution, the fan is in the Olongbluk section. The strata are mainly Quanji Formations of the Sinian, Middle Cambrian, and Upper Cambrian Series, and Duoquanshan Formations of the Lower Ordovician Series. The main lithologies include granite, quartz sandy conglomerate, limestone, dolomite, and slate. The diluvial fan is located at a fold belt between the northern margin of Qaidam and the relict mountain, which has a strong geological effect. The material carried by the river is deposited in front of the mountain, forming an interconnected plain. Most of the land surface diluvial deposits are covered by egg-stone and gravel of a poor quality. The gravel, sand, and clay are mixed and deposited together in conglomerates highly varied in size, mostly angular to sub-rounded in shape, and chaotically arranged. The layers of gravel, sand, and clay are interlaced and their profile resembles a multi-structure. The quaternary is mainly intermittent river sedimentary facies distributed in a trumpet shape through the water outlet. The material at the leading edge of the fan is coarse, mainly eggstone, gravel, and sand with poor sorting features, and the maximum particle size reaches $2.7 \mathrm{~m}$. The carrying capacity of the water flow weakens at the edge of the fan. Due to this, the accumulated material becomes gradually thinner and has a 


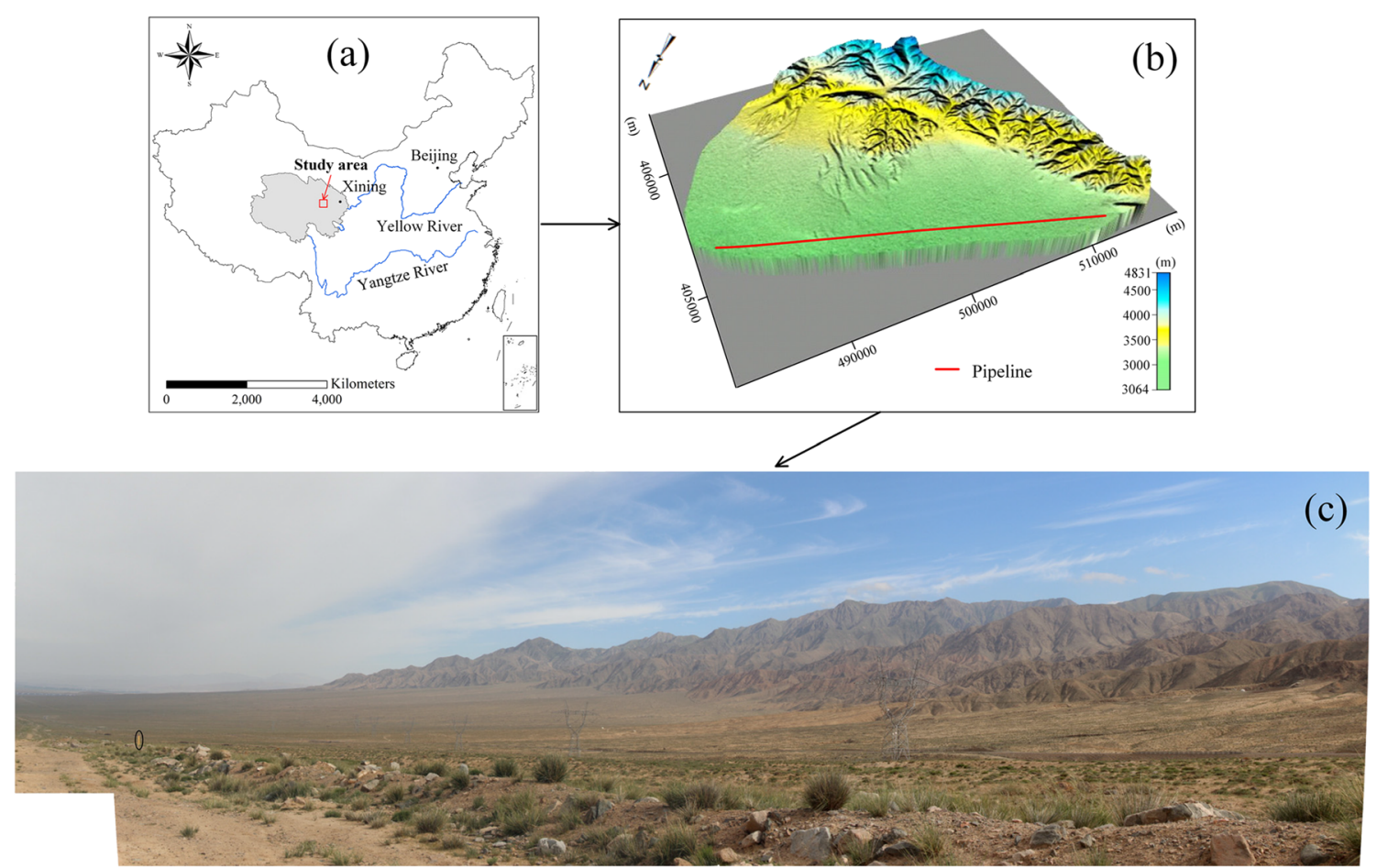

Fig. 2 Maps of the study area: (a) location and (b) three-dimensional topographic map; (c) a wide view of the fan, the black ellipse circles the pipe pile

better sorting. In this region, the sediment is formed mainly of fine sand, silt, clay, and sub-clay. There is a sedimentary rhythm in the vertical direction of the quaternary, which has a multi-layer structure.

The first and second lines of the West-East gas pipeline cross the diluvial fan for a distance of approximately $27 \mathrm{~km}$, $18 \mathrm{~m}$ apart. The average burial depth of the pipeline is $1.7 \mathrm{~m}$. Due to the influence of the local terrain, the burial depth of the pipeline at the leading edge of the diluvial fan varies from 1.4 to $2.5 \mathrm{~m}$. Our field investigation and tests were conducted on the first line of the West-East gas transmission project.

We selected this fan as the research area mainly for the following two reasons: first, the soil erosion of the fan is typical, and second, there are many geological disasters that occurred during this pipeline operation and water protection and treatment plans are urgently needed.

\section{Field tests and analysis}

\section{Samples and buffer area}

The pipe passed through the leading edge of the diluvial fan and was eroded by the water flow in varying degrees (Fig. 3a). We conducted field investigations at sites indicated by the white dotted line in Fig. 3b. To analyze the influence of the land surface properties on the susceptibility of soil erosion near the pipeline, various field tests were applied at 24 disaster points near the pipeline bank, to measure relevant indices including anti-scourability, permeability, density, inflow, and pipeline burial depth (Kheir et al. 2008). Simultaneously, four additional typical samples were selected, and a particle size distribution test was performed near the pipe bank. Establishing a certain width buffer is usually based on points, lines, and surface entities, which is convenient for analysis. Considering the safety distance between the two sides of the pipeline, a buffer distance of $200 \mathrm{~m}$ was determined (Fig. 4).

\section{Tests of land surface attributes}

The anti-scourability reflects the ability of soil to resist damage of runoff, which is closely related to its texture and structure, cementation force between particle and microstructure, and the distribution of plant roots in the soil. For the antiscourability test, the top soil at the test points was scoured by water columns at a certain height, with pressures of 0.05 , 0.10 , and $0.15 \mathrm{MPa}$, respectively. We measured the size of the water scouring holes generated by the procedure (Fig. 5a, b). The anti-scourability of the soil was calculated as the reciprocal of the mean of the product between diameter $(\mathrm{mm})$ and depth $(\mathrm{mm})$ for each of the ten sets of water scouring holes produced (SL419-2007 2008).

The permeability measures the water permeation through pores and is influenced by factors such as land surface particle size, shape, gradation, and clay content. The smaller the gap between soil particles, the smaller the permeability. There are many direct and indirect methods for determining the 

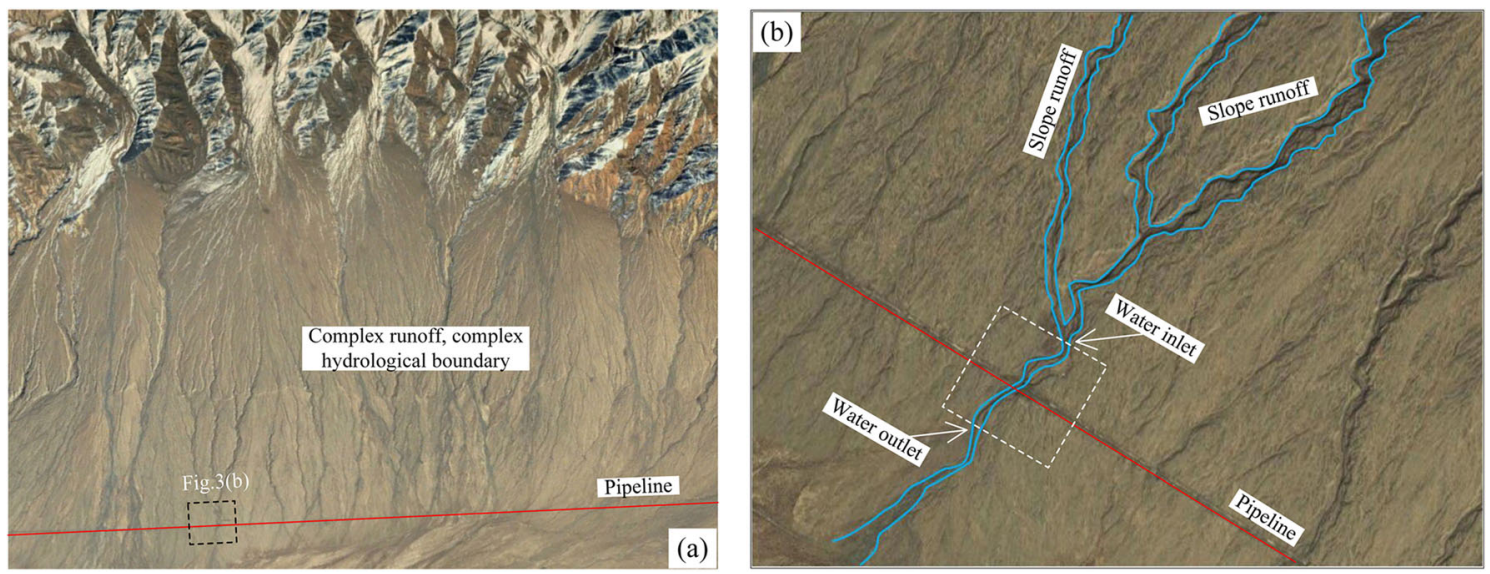

Fig. 3 Relationship between pipeline and diluvial fan. (a) Leading edge of the diluvial fan. (b) Enlarged view of near pipeline

permeability coefficient. The direct methods are divided into the constant water head and the variable water head method tests. Through indirect methods, the permeability coefficient is mainly calculated with the consolidation test and can also be calculated according to the particle size distribution. For field permeability tests, a single loop method was used to calculate the permeability coefficient, as illustrated in Fig. 5c (DL/T 5356-2006 2007). According to the magnitude of the permeability coefficient $K$, the land surface permeability is classified into the high permeability $\left(K \geq 10^{-1} \mathrm{~cm} / \mathrm{s}\right)$, medium permeability $\left(10^{-3}<K<10^{-1} \mathrm{~cm} / \mathrm{s}\right)$, and low permeability $(K \leq$ $10^{-3} \mathrm{~cm} / \mathrm{s}$ ) ranges. We measured a medium range permeability at all sample points.

The density is defined as solid particle mass per unit volume and depends on the material distribution in space; it is related to the size and mineral composition of soil. This index is obtained in laboratory using tests such as the cutting ring, wax sealing, and sand cone methods. For field measurements, the following equivalent replacement methods were selected according to different soil properties. First, we dug a round pit at the test point and weighed the mass of the excavated soil. Then, we inserted a transparent plastic bag in the pit and filled it by water injection; we calculated the water volume by weighing the water hold by the bag. The volumes of water and dug soil were equal. This information was used to determine the soil density at the test points.

Further, we selected a representative section and measured the maximum flood level with a mud mark at each test site (Fig. 5d). We defined the sectional water volume as the product of the mud mark height with the section width.

In the susceptibility assessment of the pipelines, the impact of the burial depth of the pipeline needs to be considered. We collected the depth measurements of the pipe in disaster points when pipe was laid.

To evaluate the susceptibility of the buffer zone on both sides of the pipeline, the point attributes have to be interpolated to
Fig. 4 Test points and pipeline buffer zone

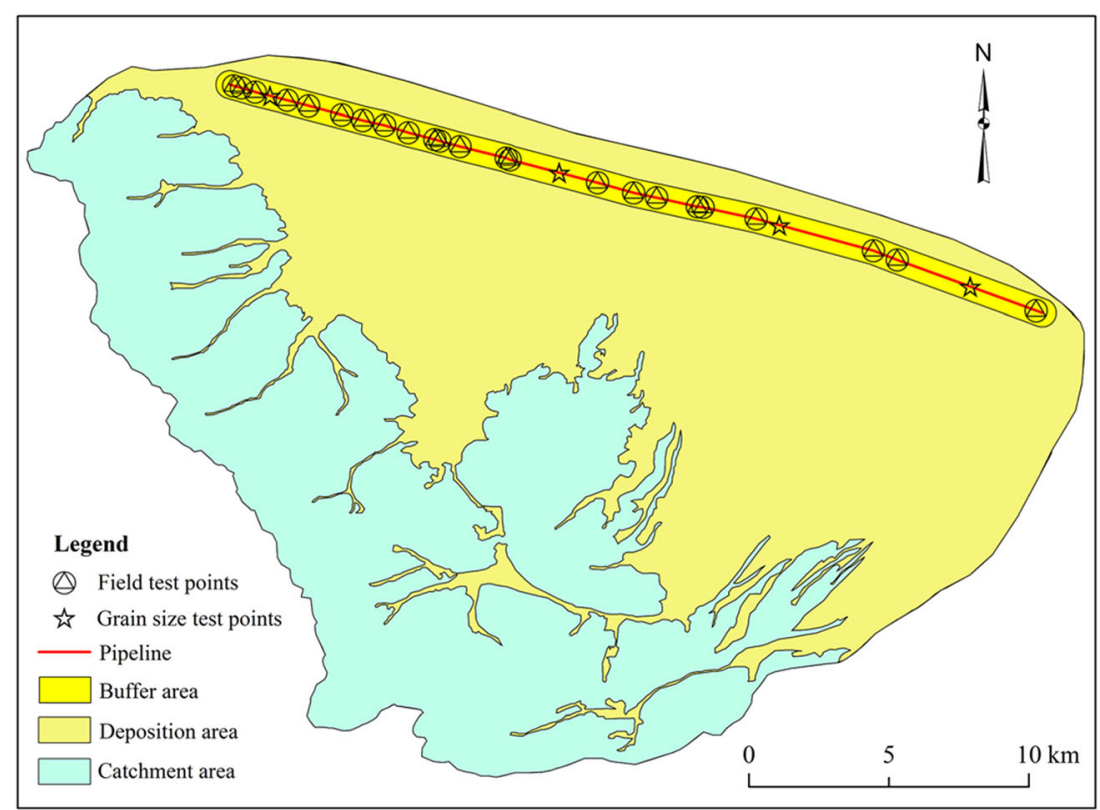



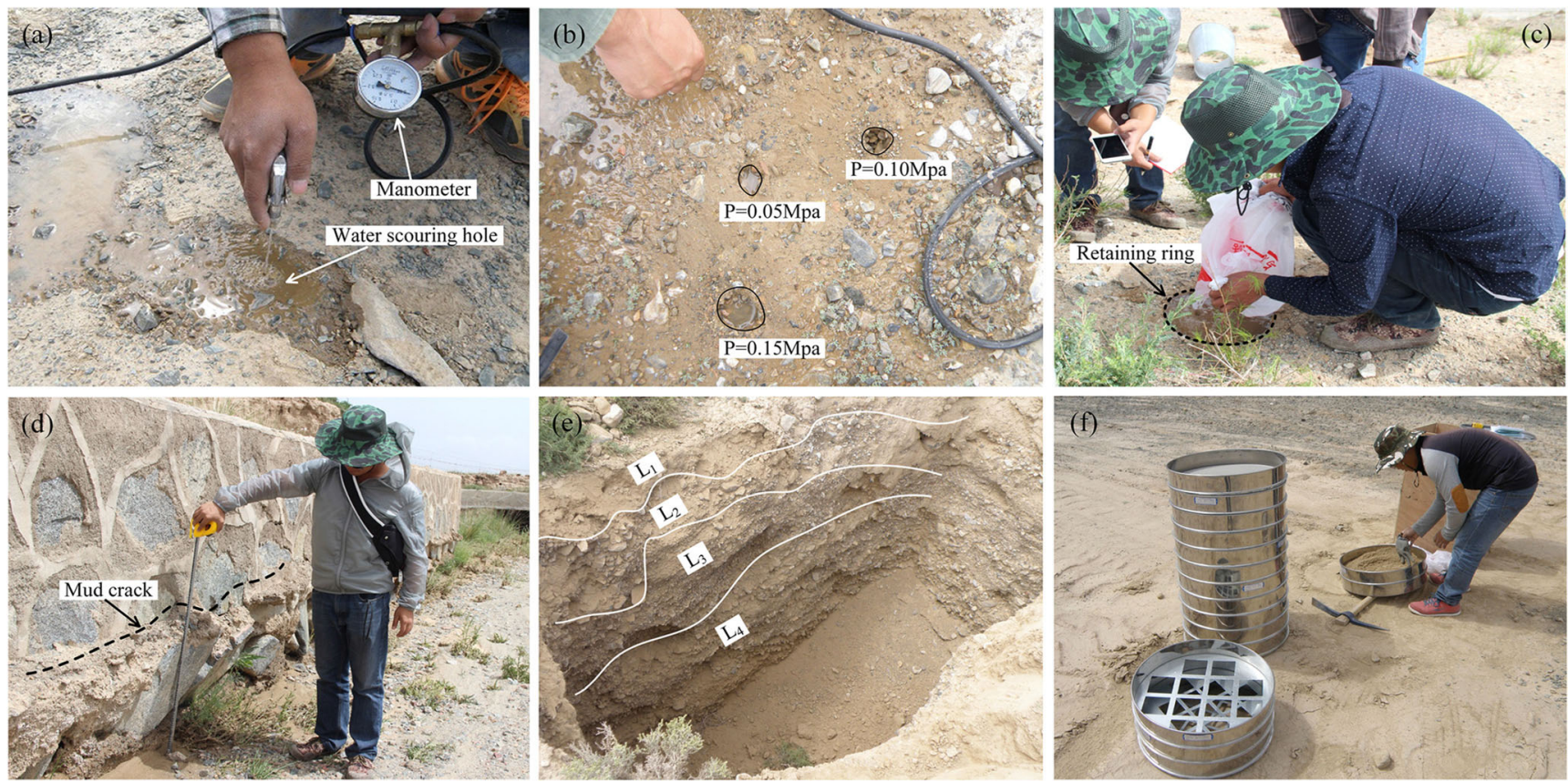

Fig. 5 Field tests. (a, b) Anti-scourability (black solid circle indicates water scouring holes). (c) Permeability (black dashed line: retaining ring preventing lateral permeation). (d) Mud crack measurement. (e) Soil

obtain the attributes of the buffer zone. After obtaining the above attributes in 24 disaster points, we obtained the spatial distribution of the attributes zone by using the ordinary kriging interpolation tool of the GIS software (Fig. 6a-e).

We dug a trench near the pipeline, to better understand the formation structure at the front edge of the diluvial fan (Fig. 5e) and classify the depositional sequence into four units, by lithology and material. Depositional units of the trench were described from the youngest to the oldest, as follows: L1: mud layer, loose and porous, $15-20 \mathrm{~cm}$; L2: sand with gravel layer, poorly sorted, subangular, 20-30 cm; L3: fine sand with silt layer, poor cementation, thickness varies laterally, 20-40 cm; L4: coarse sand layer, poor cementation, low roundness, 40$60 \mathrm{~cm}$. The particle size distribution test was done through a total of 16 (national new standard) sandstone sieves with diameter of $1 \mathrm{~m}$ and pore size from 0.15 to $90 \mathrm{~mm}$ (Fig. $5 \mathrm{f}$ ). We performed this test on the four samples presented in Fig. 4. After the $0.15-\mathrm{mm}$ sieve was used, we continued to pass the soil through a $0.075-\mathrm{mm}$ sieve in laboratory, to get the $d_{10}$ parameters. Lastly, we drew curves of the grain size distribution of the samples on land surface soil, as shown in Fig. 7, to better understand the overall distribution of particle composition on the leading edge of the diluvial fan.

\section{Extract slope grade and normalized difference vegetation index of the buffer area}

To analyze the influence of the slope grade on the susceptibility of soil erosion, we used a 10-m resolution digital elevation layers L1 (mud), L2 (sand with gravel), L3 (fine sand with silt), and L4 (coarse sand). (f) Grain size

model (DEM). The DEM was georeferenced and converted into a Universal Transverse Mercator (UTM) projection coordinate system, for further purposes. After the above steps, the slope grade of the area was extracted by the GIS software, and then, a mask process was performed, to generate the slope grade of the buffer (Fig. 6f).

The degree of vegetation development has a significant impact on runoff excretion and connection strength between soil particles. To evaluate the impact of the vegetation on soil erosion, the normalized difference vegetation index (NDVI) provides a quantitative assessment of plant growth and biomass, as an environmental parameter. We obtained the MODIS (Moderate-Resolution Imaging Spectroradiometer) data of the floodplain area from the United States Geological Survey website, and then transform the raster data through a series of means including regeneration, cropping, and normalization. Lastly, the NDVI of the buffer was calculated by the pixel binary model (Fig. 6g).

\section{Calculate weight of each index}

AHP is an effective method for determining indices weight. We established a hierarchical structure system using the pipeline susceptibility intensity as target layer, and four criterion layers, including land surface attribute $\left(B_{1}\right)$, topography and relative position $\left(B_{2}\right)$, hydrological condition $\left(B_{3}\right)$, and vegetation $\left(B_{4}\right)$ (Tudes and Yigiter 2010; Djokanović et al. 2016). The land surface attribute $\left(B_{1}\right)$ was further subdivided into three types: anti-scourability $\left(C_{1}\right)$, permeability $\left(C_{2}\right)$, and 

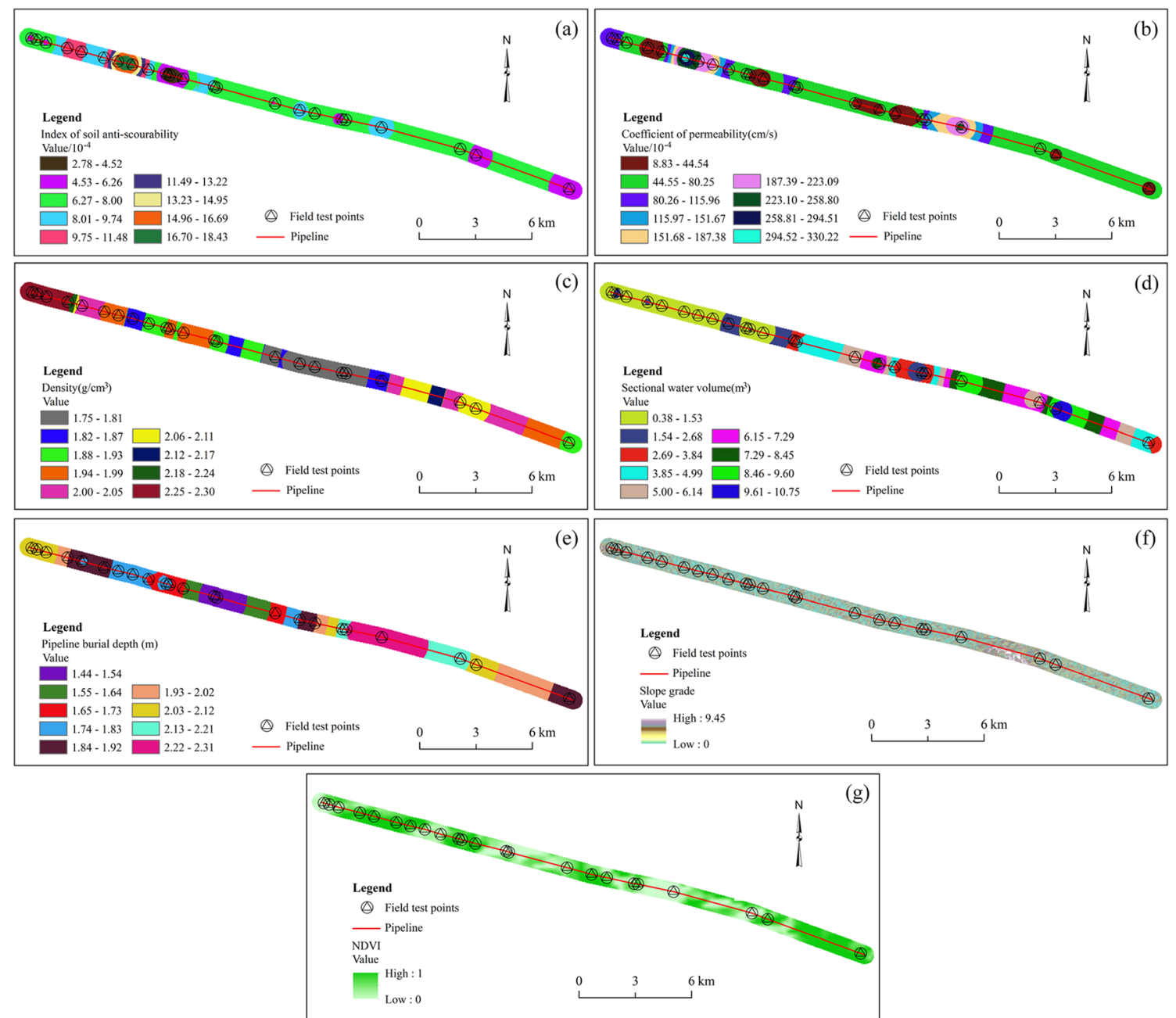

Fig. 6 Index factor acquisition of buffer zone on both sides of pipeline. (a-e) Interpolation analysis of indices in buffer area. (a) Soil anti-scourability. (b) Permeability. (c) Density. (d) Sectional water volume. (e) Pipeline burial depth. Extraction indices in buffer area: (f) slope grade and (g) NDVI

density of soil $\left(C_{3}\right)$. The topography and relative position $\left(B_{2}\right)$ could be divided into slope $\left(C_{4}\right)$, and pipeline burial depth $\left(C_{5}\right)$. The hydrological condition $\left(B_{3}\right)$ was considered by

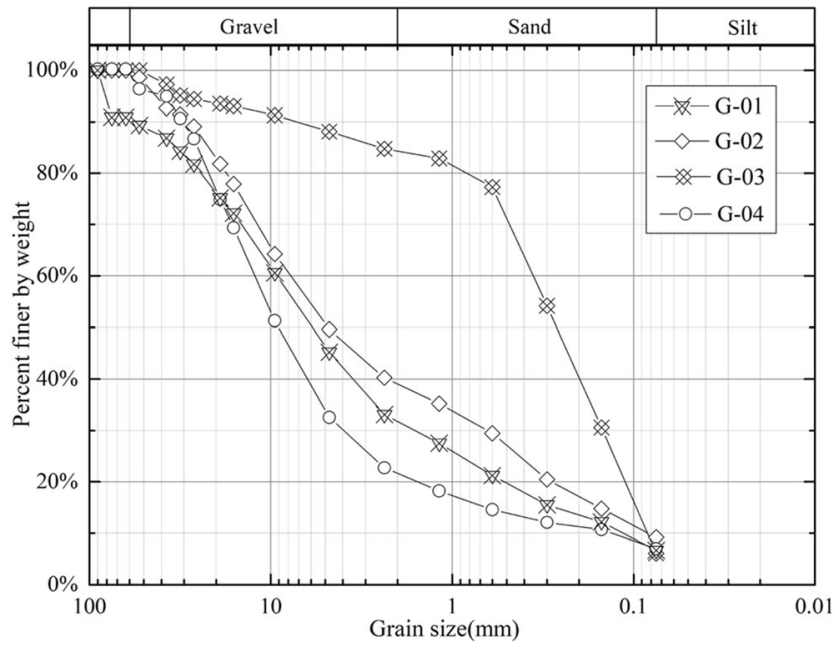

Fig. 7 Grain size distribution sectional water volume $\left(C_{6}\right)$. The vegetation $\left(B_{4}\right)$ was indicated by the NDVI of the buffer area $\left(C_{7}\right)$.

According to the importance of each index, we employed experts familiar with susceptibility evaluation of diluvial fans, based on the importance of each factor, using the 1-9 scale to quantify the index. It was assumed that the factor $B_{k}$ in $B$ layer and factors in $\mathrm{C}$ layer could be constructed and compared with each other. Therefore, we constructed three judgment matrices, as shown in Tables 1, 2, and 3 .

The weight of each index was calculated by the following steps: (1) each column of the judgment matrix was normalized and then summed by rows; (2) the summed vector was normalized as a characteristic vector; (3) the maximum characteristic root $\lambda_{\max }$ was determined. According to the order of the judgment matrix, we checked the random consistency index $R I$, calculated the ratio $I_{\mathrm{c}} / R I$, and performed the consistency check. As shown in Table 4, the consistency of each judgment matrix was within an acceptable range. Therefore, we calculated the weight of the indices after continually normalization of the 
Table 1 Judgment matrix table of standard layer

\begin{tabular}{lllll}
\hline$A$ & $B_{1}$ & $B_{2}$ & $B_{3}$ & $B_{4}$ \\
\hline$B_{1}$ & 1 & $1 / 3$ & 2 & 7 \\
$B_{2}$ & 3 & 1 & 4 & 6 \\
$B_{3}$ & $1 / 2$ & $1 / 4$ & 1 & 4 \\
$B_{4}$ & $1 / 7$ & $1 / 6$ & $1 / 4$ & 1 \\
\hline
\end{tabular}

characteristic vector which corresponded to the maximum characteristic root $\lambda_{\max }$ (Table 5).

Among all indices, we found that the weight of the slope was the highest, reaching $35.1 \%$. This result implies that a steep slope should be avoided in route design, as much as possible. In addition, the burial depth and anti-scourability exhibit similar weights, $17.5 \%$ and $17.4 \%$, respectively.

\section{Analysis of weighted overlay}

To perform the overlay analysis, we converted the rasters into a unified format. Each layer should be geospatially uniform. That is, we need a unified spatial reference (including map projection, reference ellipsoid, and datum plane), scale, and resolution. The purpose of the overlay analysis was to evaluate the relationship between spatial features and thematic attributes of spatial locations. As a result, it can not only reveal new spatial relationships but also generate new attribute characteristics. We also extracted a large amount of implicit information from the analyzed raster.

In this study, we used the same coordinate projection (WGS1984-UTM-Zone-47N) for all the rasters and vector data. A geometric correction was performed first, and then, each raster was reclassified using the GIS. According to the weight analysis, we obtained the raster map of the susceptibility intensity in the buffer area and classified it, according to the natural breakpoint method, into five levels: very high, high, medium, low, and very low (Kheir et al. 2006), as seen in Fig. 8.

\section{Results and discussion}

\section{Results of susceptibility assessment}

Figure 8 shows the susceptibility intensity distribution in the pipeline buffer area. The susceptibility intensity is generally
Table 2 Judgment matrix table of $B_{1}$ and $C_{1}-C_{3}$
Table 3 Judgment matrix table of $B_{2}$ and $C_{4}-C_{5}$

\begin{tabular}{lll}
$B_{2}$ & $C_{4}$ & $C_{5}$ \\
\hline$C_{4}$ & 1 & 2 \\
$C_{5}$ & $1 / 2$ & 1 \\
\hline
\end{tabular}

low and medium in the northwestern area (zone I), gradually increasing to a high level in the central zone of the buffer (zone II). In addition, there are few regions where the susceptibility intensity is medium. However, it is very high in zone III, and relatively high and medium in the southwestern area (zone IV).

Comparing the results of the weighted overlay analysis and the field investigation, we find that that they are consistent, which indicates that the method proposed in this study can be successfully applied for susceptibility assessment. For zone I, the analysis results show a low susceptibility intensity, and the field investigation results (Fig. 8a) reveal that the water flow at this point is relatively scattered, obliquely passing through the pipeline, and the scour depth is less than $0.1 \mathrm{~m}$. For zone II, the scour depth is approximately $0.35 \mathrm{~m}$ (Fig. 8b), consistent with the analysis results, and the risk intensity is medium. For zone II (Fig. 8d) and zone IV (Fig. 8f), the scour depth is $0.6-0.7 \mathrm{~m}$, with a trend of exposed pipe for further scouring, and the analysis shows a high erosion intensity. In zone III (Fig. 8c), the pipe is exposed, and the water flow severely scoured. In zone III (Fig. 8e), the undercut depth of the water flow reaches $1.7 \mathrm{~m}$ and the susceptibility intensity is very high, and therefore, it is necessary to strengthen the hydraulic protection. Although the depth of the pipeline in zone III is relatively deep (Fig. 6e), in this area, the intensity is the highest, due to other factors that are extremely adverse to the pipeline operation. Due to the low susceptibility, zone I suffered a weak land surface erosion with little impact on the pipeline operation (Fig. 8a), its pipeline burial depth being relatively in the middle of the pipe burial depth range.

Based on the results discussed above, we conclude that the susceptibility intensity of the pipeline is affected by the interaction of various influencing factors. To evaluate the distribution area of the susceptibility intensity in the buffer zone, we used a GIS statistical tool to determine the number of grids with the same susceptibility intensity for each intensity level, and then, we calculated their corresponding areas for all levels, as shown in Table 6 . We found that the medium, followed by the high, susceptibility intensities are prevalent

Table 4 Parameter of consistency check

\begin{tabular}{llllll}
\hline & $\lambda_{\max }$ & $n$ & $I c$ & $R I$ & $R c$ \\
\hline $\mathrm{A}$ & 4.174 & 4 & 0.058 & 0.90 & 0.064 \\
$\mathrm{~B}_{1}$ & 3.004 & 3 & 0.002 & 0.58 & 0.003 \\
\hline$R c=I c / R I, I c=\left(\lambda_{\max }-n\right) /(n-1)$ & & &
\end{tabular}

\begin{tabular}{llll}
\hline$B_{1}$ & $C_{1}$ & $C_{2}$ & $C_{3}$ \\
\hline$C_{1}$ & 1 & 3 & 5 \\
$C_{2}$ & $1 / 3$ & 1 & 2 \\
$C_{3}$ & $1 / 5$ & $1 / 2$ & 1 \\
\hline
\end{tabular}

$R c=I c / R I, I c=\left(\lambda_{\max }-n\right) /(n-1)$ 
Table 5 Weight of the indices

\begin{tabular}{lll}
\hline Classification of indexes & Indexes & Value of weight \\
\hline Land surface attribute $\left(B_{1}\right)$ & Anti-scourability $\left(C_{1}\right)$ & 0.174 \\
& Permeability $\left(C_{2}\right)$ & 0.062 \\
Topography and relative position $\left(B_{2}\right)$ & Density of soil $\left(C_{3}\right)$ & 0.033 \\
& Slope $\left(C_{4}\right)$ & 0.351 \\
Hydrological condition $\left(B_{3}\right)$ & Burial depth $\left(C_{5}\right)$ & 0.175 \\
Vegetation $\left(B_{4}\right)$ & Sectional water volume $\left(C_{6}\right)$ & 0.153 \\
\hline
\end{tabular}

in the buffer zone, covering an area of up to $19.26 \mathrm{~km}^{2}$, or $76.55 \%$ of the total area. In contrast, the low susceptibility intensity characterizes only $0.4 \mathrm{~km}^{2}$ of this zone, accounting for $1.59 \%$ of the total area. Overall, the buffer zone has a relatively high susceptibility and requires timely governance of the areas with high susceptibility intensity.

\section{Discussion the mechanism of soil erosion}

The average burial depth of the pipeline is $1.7 \mathrm{~m}$. The water erosion starts from the shallow surface, most erosion occurring mainly on the side and bottom. Therefore, we focused mainly on the susceptibility assessment of soil erosion on the

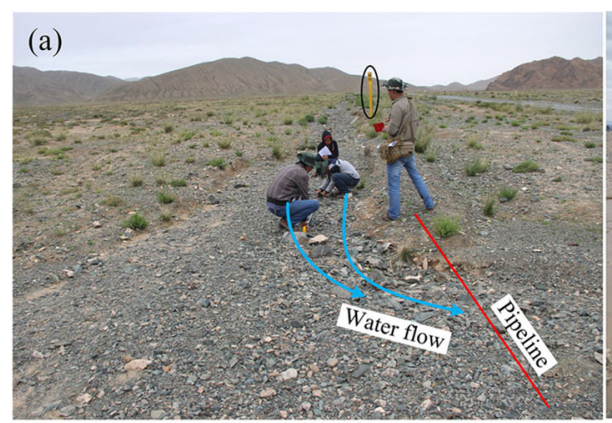

(b)
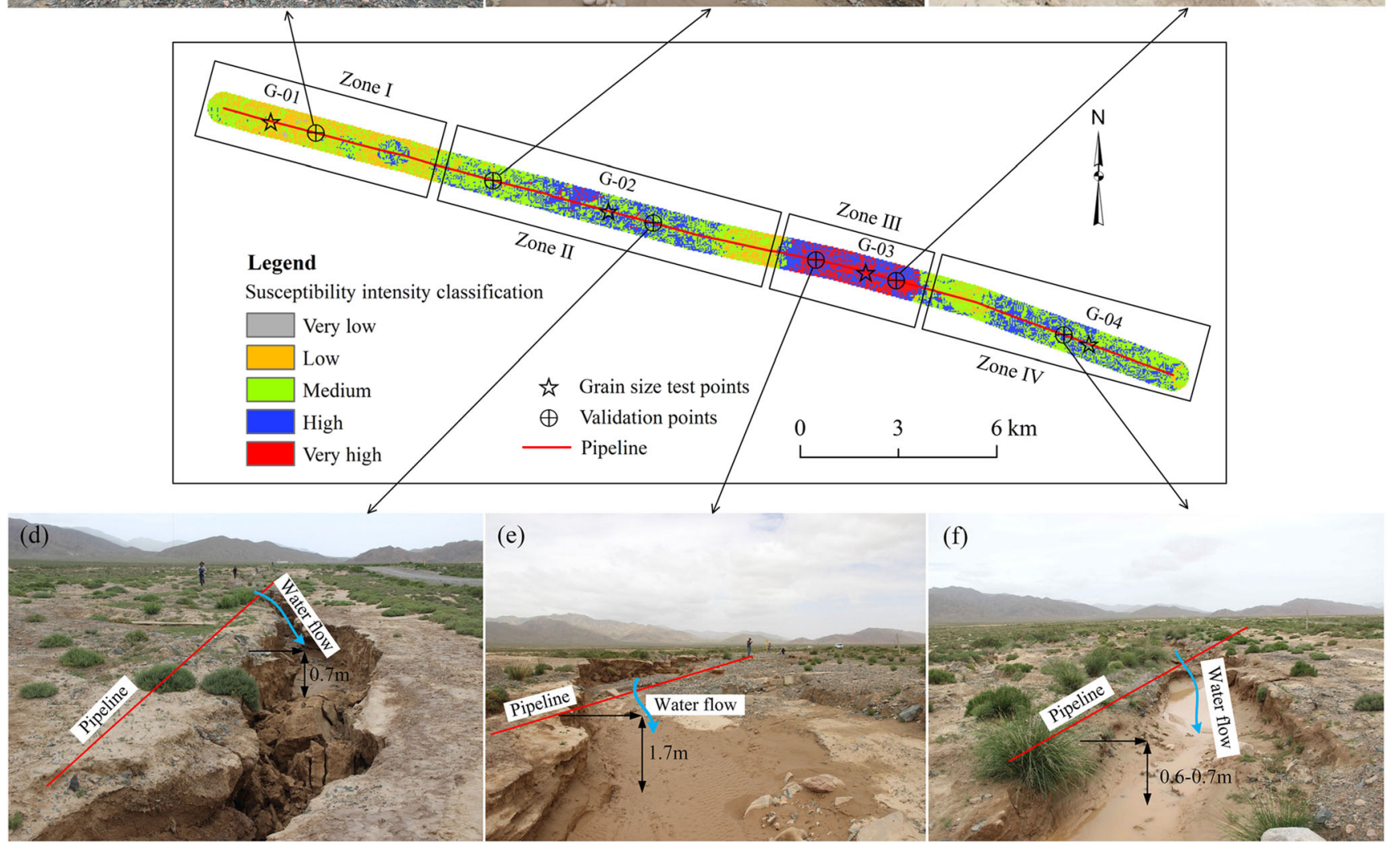

(e)

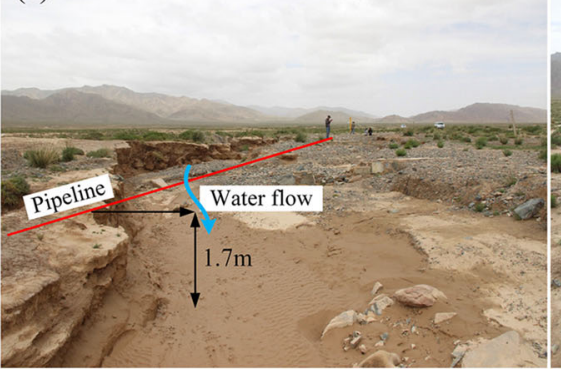

(c)

(f)

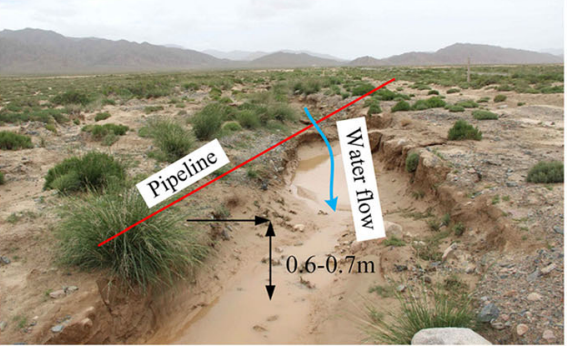

Fig. 8 Susceptibility intensity map of land surface erosion in buffer area. (a-f) represent the field investigations on pipeline disaster points 
Table 6 Area and percentage at all hazard levels in buffer zone

\begin{tabular}{lll}
\hline Hazard intensity & Area $\left(\mathrm{km}^{2}\right)$ & Percentage $(\%)$ \\
\hline Very low & 0.4 & 1.59 \\
Low & 3.89 & 15.46 \\
Medium & 11.52 & 45.79 \\
High & 7.74 & 30.76 \\
Very high & 1.61 & 6.40 \\
\hline
\end{tabular}

shallow surface near the pipeline. To determine the grading of the shallow surface soil as accurately as possible, we tested soil samples collected from the ground level to a depth of $40 \mathrm{~cm}$. Through four sets of particle size distribution tests, as shown in Fig. 7, we calculated the uneven coefficient $C_{\mathrm{u}}$ and the curvature coefficient $C_{\mathrm{c}}$ to better understand the land surface particle composition of the buffer area (Table 7).

Previously, some scholars have studied the resistance of substrate and likelihood of suffusion based on the characteristics of the particle distribution (Wohl 2004; Khaksar Najafi and Eslami 2015). As shown in Table 7, $C_{\mathrm{u}}$ is greater than 5 and $C_{\mathrm{c}}$ is in between 1 and 3 (from the G-01 test), which indicates that the particle is not uniform and the gradation is accurate in zone I. The susceptibility intensity is generally low and medium in this area mainly because fine particles fill the porous structure between large particles, reducing the permeability of the soil, and preventing water flow in the soil. Moreover, the particle interaction makes it difficult for the soil particle to be carried away. Further, in zone I, the root system of the vegetation cover enhances the soil aggregation by changing the soil structure, significantly improving the erosion resistance of the land surface (Pollen and Simon 2005).

The uneven coefficient $\left(C_{\mathrm{u}}\right)$ is less than 5 , and the curvature coefficient $C_{\mathrm{c}}$ is less than 1 (G-03; Table 7), indicating that the particle gradation of the area is extremely poor. As shown in Fig. 7, the soil particles size varies mainly between 0.075 and $0.6 \mathrm{~mm}$, and therefore, the occlusion and cementation between particle are particularly weak, leading easily to soil loss. The soil erosion in this section is extremely severe and the susceptibility intensity is mainly high and very high during the pipeline operation, as shown in Fig. 8c, e. Moreover, the vegetation coverage of this area is relatively low (Fig. 6g). In addition, this section corresponds to the largest area of the

Table 7 Grading coefficient of four groups of grain size tests

\begin{tabular}{lll}
\hline Grain size no. & \multicolumn{2}{l}{ Gradation index } \\
\cline { 2 - 3 } & $C_{\mathrm{u}}$ & \multicolumn{1}{l}{$C_{\mathrm{c}}$} \\
\hline G-01 & 85.45 & 2.18 \\
G-02 & 97.53 & 0.60 \\
G-03 & 4.20 & 0.82 \\
G-04 & 84.17 & 12.87 \\
\hline
\end{tabular}

catchment (Fig. 4), which also has the largest amount of water, as shown in Fig. 6d. The unfavorable combination of the above factors led to the highest susceptibility in zone III, as shown in Fig. 8c, e.

The uneven coefficient $\left(C_{\mathrm{u}}\right)$ is more than 5 in both of zone II and zone IV, while the curvature coefficient $C_{\mathrm{c}}$ is less than 1 and, respectively, more than 3 . This indicates that the gradation of these two zones is general. The particle size is mostly small in zone II. However, it is larger in zone IV. Consequently, the susceptibility density of the pipeline in these two areas is mainly high and locally medium in both zone II and zone IV (Fig. $8 \mathrm{~d}, \mathrm{f})$. In these two zones, the gradation of the shallow surface soil is not conducive to maintenance of the soil. After surface erosion, the side and bottom erosion are a greater threat to the pipeline operation.

The gradation of the soil has an important effect on the erosion of soil in the buffer (Cao et al. 2018). It was found during gully erosion investigation that sand (top) layer has higher water permeability than muddy (bottom) layer and top layer showed $74 \%$ sand, $7.2 \%$ silt, and $18.8 \%$ clay, respectively, while $23.8 \%$ sand, $18.2 \%$ silt, and $58 \%$ clay for the bottom layer. The implication of this finding is that with high proportion of sand at the top layer infiltration is high, while low infiltration at the bottom layer due high proportion of clay content (Mbaya et al. 2012). In this study, the relationship between the content of various components of shallow surface and erosion intensity is shown in Fig. 9. The higher the silt content of the surface, the stronger the erosion intensity. The silt content of G-03 is $35.6 \%$, showing the highest erosion intensity; for G-04, it is mainly large particles, and the gravel content is $78.7 \%$, and for G-02, the sand and silt content is close to $40 \%$, indicating the presence of many fine particles, and the erosion intensity is high at these two points; for G-01, silt content is relatively low with uniform particles, and the erosion intensity is low. The mud layer is a kind of interlayer, which is distributed on the upper layer. Due to the weathering, it presents porous porosity (Fig. 5e).

As Fig. 10a-c show, there are two main layers: the upper layer is poorly graded muddy sediments, and the second layer is sand. It also can be seen from Fig. 10b, c, the cementation of the muddy sedimentary is very poor, and there are several avalanche mass, as shown in black dotted line. However, when the mud layer is distributed in the lower layer, due to the high degree of consolidation and poor water permeability, the erosion will be reduced accordingly. As Fig. 10d shows the upstream is sand layer, the erosion depth is up to $1.6 \mathrm{~m}$. With the appearance of $0.15 \mathrm{~m}$ interlayer in the middle layer, the erosion depth decreases sharply due to the influence of mud layer (Fig. 10e). Due to the divergence of water flow, the flow decreases and the undercut depth becomes smaller as the flow goes downstream (Fig. 10f). Terwindt argued that the resistance of sand-clay laminations to erosion is great (Terwindt et al. 1968). The interlayer in diluvial fan is mainly 


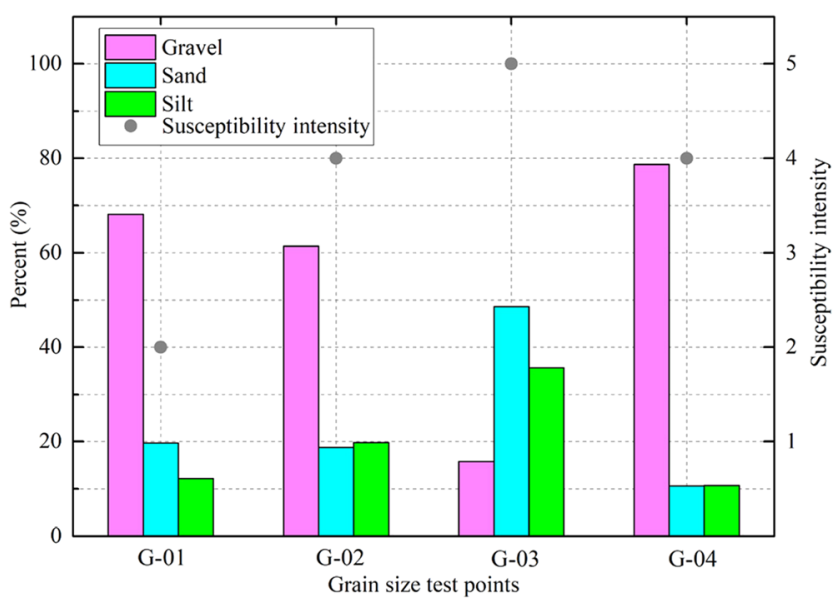

Fig. 9 The relationship between the composition of each grain size points and susceptibility intensity, $1-5$ corresponding to very low, low, medium, high, and very high, respectively

small granular clay. It is loose and porous when it is on the surface; while it has high degree of consolidation and poor water permeability when it is interlayer. In this investigation, when the interlayer is more than $15 \mathrm{~cm}$, it has a serious impact on soil erosion. As a result, this may be due to the interaction between particles, such as the filling and blocking of fine particle can reduce the soil erosion.

The location and thickness of the muddy layer will affect the particle gradation of the shallow surface soil, while the erosion of water flow to the soil starts from the shallow surface, and then is affected by the terrain, with different degrees of lateral erosion and undercutting erosion. Lateral erosion makes the channel wider, and undercutting erosion makes the channel deeper, showing retrogressive erosion at the source of channel. As shown in Fig. 11a, due to the influence of local topography, the water flow swings laterally and erodes the bank of the channel, and the bank collapses, accompanied by the widening of the channel. The process of retrogressive erosion is the undercutting with the flow convergence and the original channel is formed (Fig. 11b). With the formation and evolution of the channel, the susceptibility of soil erosion increases accordingly.

\section{Conclusions}

To evaluate the soil erosion in overlaying diluvial fans of shallow underground pipelines, we propose a method for susceptibility assessment of soil erosion. This method requires soil erosion parameters including internal soil factors, such as anti-scourability, permeability, and density; external factors, such as water flow, slope, and vegetation; and factors of the project itself, such as pipeline burial depth. The susceptibility assessment results of the analysis were compared with the field investigation. Finally, the mechanism of shallow soil erosion is discussed.

The following conclusions can be drawn:

1. The results obtained by the proposed method and the actual erosion assessment by field investigation are in good agreement. This indicates that this method can be successfully used for susceptibility assessment. Furthermore, the proposed method can be applied to analyze the
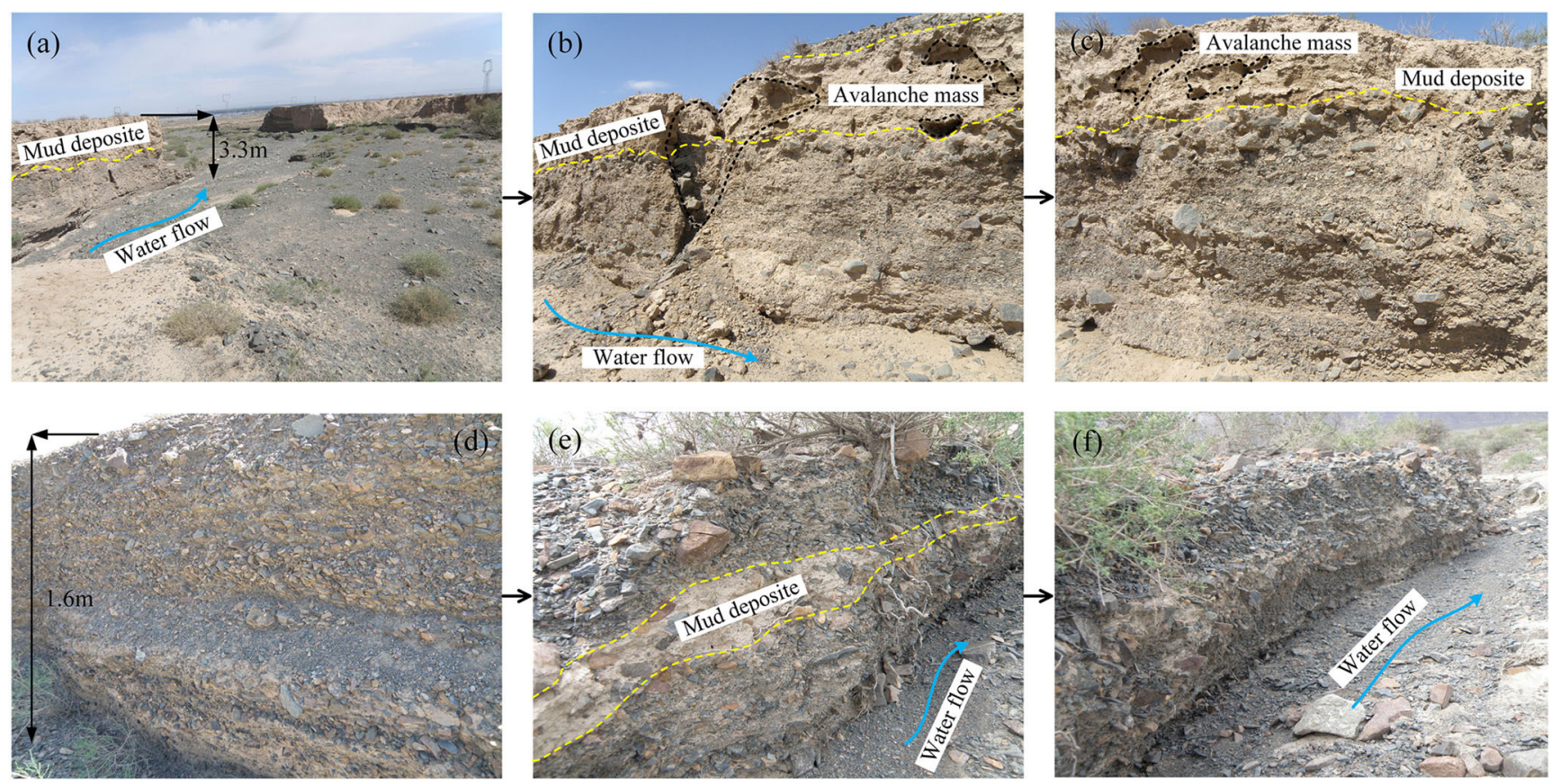

Fig. 10 Influence of surface composition on erosion intensity. (a-c) Uneven and complex soil particle in stratigraphic layers. (d-f) Relatively uniform soil particle in stratigraphic layers, the interlayer in (e) is about $15 \mathrm{~cm}$ 

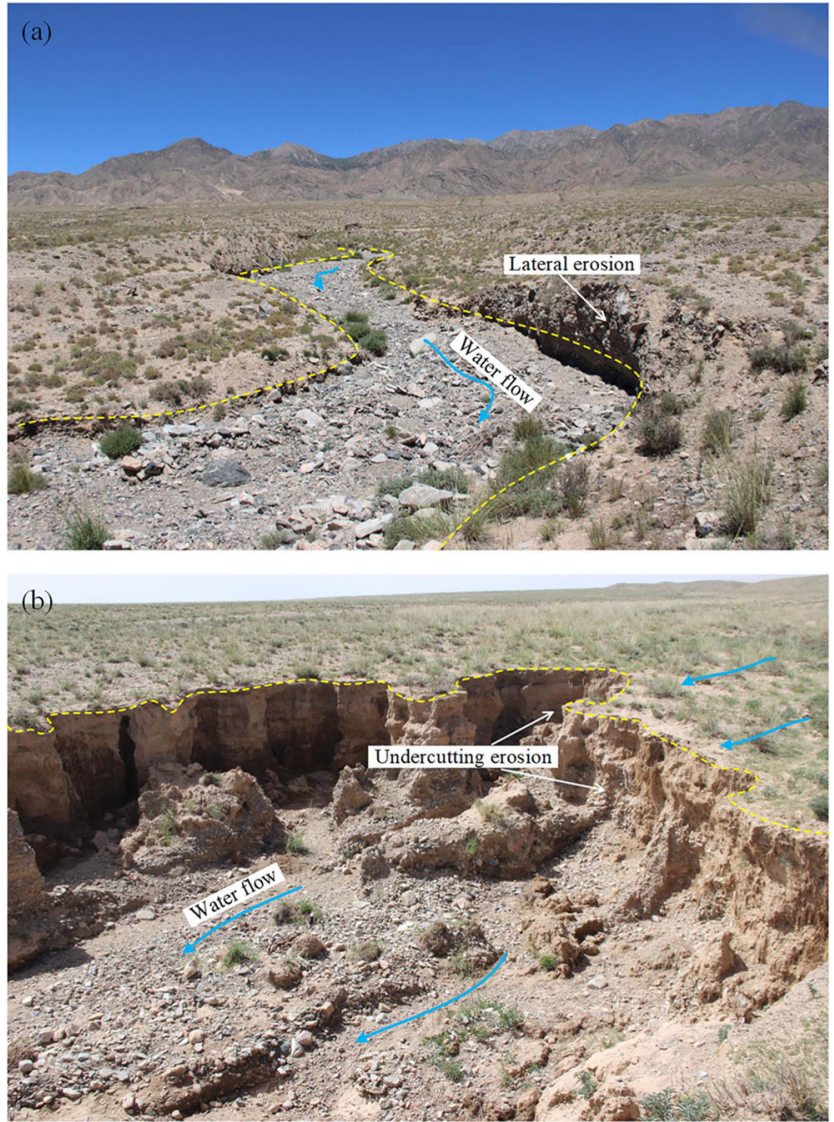

Fig. 11 Two main types of gully erosion: (a) lateral erosion; (b) undercutting erosion

susceptibility of soil erosion when other line projects cross diluvial fans.

2. The area of the medium susceptibility intensity in the buffer zone is the largest, followed by the high susceptibility intensity area. These areas cover a total of approximately $19.26 \mathrm{~km}^{2}$, accounting for $76.55 \%$ of the total buffer zone. Overall, the susceptibility level in the buffer area is relatively high, and corresponding governance measures need to be strengthened in a timely manner.

3. The occlusion and cementation of the meso-particles reveal the susceptibility intensity of the soil erosion. The susceptibility is low where the soil particles are uneven with a good gradation. On the contrary, the soil particles are extremely easy to be carried away in areas with uniform particles and poor gradation, which leads to a high susceptibility of soil erosion.

4. The effective and efficient susceptibility assessment method proposed can be extended to environmental and ecological protection in arid and semi-arid areas. Furthermore, susceptibility assessments of regional soil erosion can be conducted and can contribute to better key management and protection.
The limitations of the proposed method mainly relate to the use of a simplified hypothesis that the project has little effect on the upstream water flow; nevertheless, the findings are easily exportable to other sites. Besides, the method is focused on the susceptibility assessment of soil erosion of oil and gas pipelines, and also suitable for other linear projects. It is necessary to select indicators and determine weight again in combination with specific engineering.

Acknowledgments The authors would like to acknowledge the anonymous reviewers and the Editors for valuable comments, which allowed substantially improving the paper.

Funding This study received financial support from the National Natural Science Foundation of China (41672286, 41977213, 41761144080); the Second Tibetan Plateau Scientific Expedition and Research Program(STEP) (2019QZKK0906); the Science \& Technology Department of Sichuan Province (20GJHZ0232); Innovation-Driven Project of Central SouthUniversity (2019CX011). The financial support received from theseorganizations is gratefully acknowledged.

Open Access This article is licensed under a Creative Commons Attribution 4.0 International License, which permits use, sharing, adaptation, distribution and reproduction in any medium or format, as long as you give appropriate credit to the original author(s) and the source, provide a link to the Creative Commons licence, and indicate if changes were made. The images or other third party material in this article are included in the article's Creative Commons licence, unless indicated otherwise in a credit line to the material. If material is not included in the article's Creative Commons licence and your intended use is not permitted by statutory regulation or exceeds the permitted use, you will need to obtain permission directly from the copyright holder. To view a copy of this licence, visit http://creativecommons.org/licenses/by/4.0/.

\section{References}

Aksoy H, Kavvas ML (2005) A review of hillslope and watershed scale erosion and sediment transport models. Catena 64(2):247-271. https://doi.org/10.1016/j.catena.2005.08.008

Baartman JE, Jetten VG, Ritsema CJ, Vente J (2012) Exploring effects ofrainfall intensity and duration on soil erosion at the catchment scale using openLISEM: Prado catchment, SE Spain. Hydrol Process 26(7):1034-1049. https://doi.org/10.1002/hyp.8196

Barnes JB, Heins WA (2010) Plio-Quaternary sediment budget between thrust belt erosion and foreland deposition in the central Andes, southern Bolivia. Basin Res 21(1):91-109. https://doi.org/10.1111/ j.1365-2117.2008.00372.x

Beven K (1989) Changing ideas in hydrology — the case of physicallybased models. J Hydrol 105:157-172. https://doi.org/10.1016/00221694(89)90101-7

Bull WB (1977) The alluvial fan environment. Prog Phys Geogr 1:222 270. https://doi.org/10.1177/030913337700100202

Cao CL, Sun YF, Sun HF, Song YP (2018) Erosion resistance and scouring depth of fine-grained seabed of the Huanghe River estuary, China. Bull Eng Geol Environ 77(3):897-910. https://doi.org/10. 1007/s10064-017-1148-7

Clevis Q, Boer PD, Wachter M (2003) Numerical modelling of drainage basin evolution and three-dimensional alluvial fan stratigraphy. Sediment Geol 163(1):85-110. https://doi.org/10.1016/s00370738(03)00174-x 
Corominas J, Westen CV, Frattini P, Cascini L, Malet JP, Fotopoulou S, Catani $\mathrm{F}$ et al (2013) Recommendations for the quantitative analysis of landslide risk. Bull Eng Geol Environ:1-55. https://doi.org/10. 1007/s10064-013-0538-8

Cuomo S, Della Sala M, Novità A (2015) Physically based modelling of soil erosion induced by rainfall in small mountain basins. Geomorphology 243:106-115. https://doi.org/10.1016/j.geomorph. 2015.04.019

Cuomo S, Della Sala M, Pierri M (2016) Experimental evidences and numerical modelling of runoff and soil erosion in flume tests. Catena 147:61-70. https://doi.org/10.1016/j.catena.2016.06.044

De Roo APJ, Jetten VG (1999) Calibrating and validating the LISEM model for two data sets from the Netherlands and South Africa. Catena 37(3-4):477-493. https://doi.org/10.1016/S0341-8162(99) 00034-X

De Roo APJ, Wesseling CG, Ritsema CJ (1996) LISEM: a single event physically-based hydrologic and soil erosion model for drainage basins. I: theory, input and output. Hydrol Process 10:1107-1117

Djokanović S, Abolmasov B, Jevremović D (2016) GIS application for landfill site selection: a case study in Pančevo, Serbia. Bull Eng Geol Environ 75(3):1273-1299. https://doi.org/10.1007/s10064-0160888-0

DL/T5356-2006 (2007) Code for coarse-grained soil tests for hydropower and water conservancy engineering. National Development and Reform Commission, P.R. China (in Chinese)

Eriksson MG, Olley JM, Payton RW (2000) Soil erosion history in central Tanzania based on OSL dating of colluvial and alluvial hillslope deposits. Geomorphology 36:107-128. https://doi.org/10.1016/ S0169-555X(00)00054-4

Ferro V, Porto P (2000) Sediment delivery distributed (SEDD) model. J Hydrol Eng 5(4):411-422. https://doi.org/10.1061/(ASCE)10840699(2000)5:4(411)

Granger DE, Kirchner JW, Finkel R (1996) Spatially averaged long-term erosion rates measured from in situ-produced cosmogenic nuclides in alluvial sediment. J Geol 104(3):249-257

Hessel R, Jetten V, Liu B, Zhang Y, Stolte J (2003) Calibration of the LISEM model for a small Loess Plateau catchment. Catena 54:235254. https://doi.org/10.1016/S0341-8162(03)00067-5

Hessel R, van den Bosch R, Vigiak O (2006) Evaluation of the LISEM soil erosion model in two catchments in the East African highlands. Earth Surf Process Landf 31:469-486. https://doi.org/10.1002/esp.1280

Hinderer M (2012) From gullies to mountain belts: a review of sediment budgets at various scales. Sediment Geol 280(4):21-59

Khaksar Najafi E, Eslami A (2015) Assessment of the likelihood of suffusion in alluvial soils: case history. Bull Eng Geol Environ 74(2): 611-620. https://doi.org/10.1007/s10064-014-0681-x

Kheir RB, Cerdan O, Abdallah C (2006) Regional soil erosion risk mapping in Lebanon. Geomorphology 82:347-359. https://doi.org/10. 1016/j.geomorph.2006.05.012

Kheir RB, Abdallah C, Runnstrom M, Martensson U (2008) Designing erosion management plans in Lebanon using remote sensing, GIS and decision-tree modeling. Landsc Urban Plan 88:54-63. https:// doi.org/10.1016/j.landurbplan.2008.08.003

Kuhlemann J, Frisch W, Székely B, Dunkl I, Kázmér M (2002) Postcollisional sediment budget history of the Alps: tectonic versus climatic control. Int J Earth Sci 91(5):818-837. https://doi.org/10. 1007/s00531-002-0266-y

Mbaya LA, Ayuba HK, Abdullahi J (2012) An assessment of gully erosion in Gombe town, Gombe state, Nigeria. J Geogr Geol 4(3):110 121. https://doi.org/10.5539/jgg.v4n3p110

Merritt WS, Latcher RA, Jakeman AJ (2003) A review of erosion and sediment transport models. Environ Model Softw 18:761-799. https://doi.org/10.1016/S1364-8152(03)00078-1

Morgan RPC, Quinton JN, Smith RE, Govers G, Poesen JWA, Auerswald K, Chisci G, Torri D, Styczen ME (1998) The
European soil erosion model (EUROSEM): a process-based approach for predicting sediment transport from fields and small catchments. Earth Surf Process Landf 23:527-544

Nishiizumi K, Caffee MW, Finkel RC, Brimhall G, Mote T (2005) Remnants of a fossil alluvial fan landscape of Miocene age in the Atacama Desert of northern Chile using cosmogenic nuclide exposure age dating. Earth Planet Sci Lett 237:499-507. https://doi.org/ 10.1016/j.epsl.2005.05.032

Pollen N, Simon A (2005) Estimating the mechanical effects of riparian vegetation on stream bank stability using a fiber bundle model. Water Resour Res 41:W07025. https://doi.org/10.1029/ 2004wr003801

Roberts N, Black S, Boyer P, Eastwood WJ, Griffiths HI, Lamb HF, Leng MJ, Parish R, Reed JM, Twigg D, Yigitbasioglu H (1999) Chronology and stratigraphy of Late Quaternary sediments in the Konya basin, Turkey: results from the KOPAL project. Quat Sci Rev 18:611-630. https://doi.org/10.1016/S0277-3791(98)00100-0

Sancho C, Pena JL, Rivelli F et al (2008) Geomorphological evolution of the Tilcara alluvial fan (Jujuy Province, NW Argentina): tectonic implications and palaeoenvironmental considerations [J]. J S Am Earth Sci 26(1):0-77. https://doi.org/10.1007/s11069-015-1728-4

Santo A, Santangelo N, Crescenzo GD, Scorpio V, Falco MD, Chirico GB (2015) Flash flood occurrence and magnitude assessment in an alluvial fan context: the October 2011 event in the Southern Apennines. Nat Hazards 78(1):417-442. https://doi.org/10.1007/ s11069-015-1728-4

SL419-2007 (2008) Test specification of soil and water conservation. Ministry of Water Resources, P.R. China (in Chinese)

Sorooshian S (1991) Parameter estimation, model identification, and model validation: conceptual-type models. In: Bowles DS, O'Connell PE (eds) Recent advances in the modelling of hydrologic systems, NATO ASI Series, vol 345, pp 443-467. https://doi.org/ 10.1007/978-94-011-3480-4 20

Terwindt JHJ, Breusers HNC, Svasek JN (1968) Experimental investigation on the erosion-sensitivity of a sand-clay lamination. Sedimentology 11(1-2):105-114. https://doi.org/10.1111/j.13653091.1968.tb00844.x

Tipping R, Halliday SP (2010) The age of alluvial fan deposition at a site in the southern uplands of Scotland. Earth Surf Process Landf 19(4): 333-348. https://doi.org/10.1002/esp.3290190405

Tudes S, Yigiter ND (2010) Preparation of land use planning model using GIS based on AHP: case study Adana-Turkey. Bull Eng Geol Environ 69(2):235-245. https://doi.org/10.1007/s10064-009-02475

Veihe A, Rey J, Quinton JN, Strauss P, Sancho FM, Somarriba M (2001) Modelling of event-based soil erosion in Costa Rica, Nicaragua and Mexico: evaluation of the EUROSEM model. Catena 44(3):187203. https://doi.org/10.1016/S0341-8162(00)00158-2

Vente JD, Poesen J (2005) Predicting soil erosion and sediment yield at the basin scale: scale issues and semi-quantitative models. Earth-Sci Rev 71(1-2):95-125. https://doi.org/10.1016/j.earscirev.2005.02. 002

Wischmeier WH, Smith DD (1978) Predicting rainfall erosion losses: a guide to conservation planning. Agriculture Handbook 537. US Department of Agriculture, Washington, DC

Wohl E (2004) Limits of downstream hydraulic geometry. Geology 32: 897-900. https://doi.org/10.1130/g20738.1

Yang G, Zhang X, Tian M et al (2011) Geomorphological and sedimentological comparison of fluvial terraces and karst caves in Zhangjiajie, northwest Hunan, China: an archive of sandstone landform development. Environ Earth Sci 64(3):671-683. https://doi. org/10.1007/s12665-010-0887-6

Young RA, Onstad CA, Bosch DD et al (1989) AGNPS: a nonpointsource pollution model for evaluating agricultural watersheds. J Soil Water Conserv 44(2):4522-4561 